\title{
Survey of Corporate Financial Behavior of Indian MNCs
}

\author{
Anu Kohli \\ Department of Business Administration, University of Lucknow \\ Lucknow, 226007 India \\ E-mail: kohli_a@lkouniv.ac.in \\ Jitendra Kumar Sharma (Corresponding author) \\ Department of Business Administration, University of Lucknow \\ Lucknow, 226007 India \\ E-mail: sharma_jk@lkouniv.ac.in
}

Received: 06-03- 2015

doi:10.7575/aiac.ijfas.v.3n.1p.12
Accepted: 08-04- 2015

Published: 30-04- 2015

\begin{abstract}
This paper attempts to capture the similarities and differences in the corporate financial behavior of Indian MNCs. The primary information has been collected through responses of senior financial executives of identified Indian MNCs on a questionnaire developed on well-known Duke Special Survey on Corporate Financial Policies (Graham \& Harvey, 2001) with addition of twelve questions to comprehensively cover various aspects of corporate financial practices by Indian MNCs. Though results indicate similarities to a large extent in investment, financing, management control and dividend practices but significant differences are also observed in practices. The results support previous studies in corporate financial behavior of companies exhibiting differences in their practices due to their size and industry characteristics. It further extends to identifying differences in their behavior attributable to differences in multinationality rank, number of foreign subsidiaries and foreign equity holdings.
\end{abstract}

Keywords: Corporate financial behavior, MNC finance

\section{Introduction}

India has seen the emergence of Indian MNCs a decade after the financial sector reforms, with the improvement in the financial resources of many of these companies. Financial strategy adopted by a MNC can provide competitive advantage through low cost of funds and flexibility to raise capital to support a business strategy. Functional Strategy provides a blueprint of how financial activities will be managed in supporting business strategy \& achieving the financial department's objectives \& missions. (Thompson et al., 2003).

As the emergence of Indian MNCs is relatively a recent phenomenon, there are many areas that need to be explored to understand the nature of decision making, evolving management structures and nature of financial policies and practices required to successfully execute the strategies in the complex and dynamic international environment. Recent maturing of some of the Indian companies in establishing international presence prompted us to undertake this study to understand the practices and linkages of financial decisions of Indian MNCs at the corporate, business \& functional level.

This paper has been attempted to address the objective of identifying differences if any in the prevalent corporate finance practices and behavior of Indian Multinational Companies based on their Industry representation, multinationality ranking, size of assets, foreign equity holding percentage or number of foreign subsidiaries.

\section{Literature Review}

The effectiveness of the corporate finance function in any organization affects its performance. Many factors such as ownership pattern, parent's claim on cash flow, concentration of control affect both the performance as well as company valuation (Rossi and Cebula, 2015). In their examination of announcements of board of directors of 100 companies listed on Italian stock market for changes in board size, composition, mix of executive or non-executive directors, they found market reaction in support of signaling theory but found no evidence of positive market reaction because of larger women composition of the board and evidence of negative reaction in case of larger board size or majority number of independent directors. Sharma \& Pandey (2015) suggested correlating ownership structures with abnormal returns to help explain governance issues. This leads us to rely more on the attribution theory reflecting financial behavior. Behavioral corporate finance as a discipline integrates human element in decision making in uncertain situations (Adler, 2004). Board of directors have a significant role to play in the realm of corporate finance as financial expertise is regarded as the most important attribute of a director even more important than the industry and operational expertise. Given the composition of the board, financial attributes of the directors shape the financial policy 
to a large extent $(\mathrm{PwC}, 2014)$ and the personal risk profile of CEO's to some extent also contributes to behavioral consistency in corporate finance behavior exhibited by companies (Cronqvist, et al., 2012).

Graham \& Harvey (2001) in their survey of Fortune 500 firms found support for use of NPV and CAPM and lesser support for consideration of factors taught in theory regarding capital structure decisions in practice. They attribute differences in practice of corporate finance by firms due to size effects. Survey of CFO's in India by Anand (2002) also found use of basic finance tools in practice but variation in practices due to size. In their survey of five countries selected from three continents, Cohen \& Yagil, (2007) observed corporate decision making process is generally consistent with expectation of theory and observed differences in corporate financial practices are due to variations in economic environments of countries studied. Extending their work to research sectorial differences in corporate financial behavior, Cohen \& Yagil, (2010) found differences in the use of techniques and relative importance to factors considered in investment, financing and dividend related practices by companies in different sectors and attributed these differences to unique financial needs and operational conditions of each sector and imitation effect. Saha ( 2012) highlighted preferences in use of capital budgeting techniques, relative preference for return versus financial flexibility in capital structure decisions, concerns in financing debt and equity and factors weighing in dividend payout vs. share repurchase through survey of 20 Indian CFO's. There exists a vacuum of studies on corporate finance practices of Indian MNCs to identify differences in practices attributable to the individual characteristics and make-up of companies. This study is different from all previous studies primarily due to extent of coverage to investment, financing, management control and dividend decision and examines corporate financial practices of Indian MNCs and differences in practices of these MNCs arising out of their industry representation, size, number of foreign subsidiaries and foreign equity holding.

\section{Methodology}

\subsection{Instrument for Primary Data Collection}

The primary data for the study was generated through a questionnaire instrument designed to solicit responses on various aspects of corporate financial decisions from senior level finance executives of Indian MNCs.

Our survey instrument consists of 22 well-structured questions with focus on extracting information on investing, financing, dividend and management control decisions. Ten questions in the instrument are same as used the in the wellknown Duke Special Survey on Corporate Financial Policies (Graham \& Harvey, 2001), with permission of Prof. John Graham whose original instrument has been previously used in Brazil, North America and Europe. Twelve new questions were framed to seek detailed information on various additional aspects of financial decision making by Indian MNCs through responses solicited on the scale of 0 to 4 during the financial year 2012-13.

\subsection{Calculation of Multi-Nationality Index (MNI) of Indian Companies}

The Economics Times Intelligence Group (ETIG- 500) listing of companies for the year 2011 was used as initial database. Our sample of ETIG- 500 companies represent large companies exhibiting profits and higher market capitalization as compared to smaller companies outside the ETIG database. These companies as part of their strategic moves takes more risk in overseas markets. This propensity of size effect on risk taking is also observed in European Banking Industry (Mattana et al, 2014). Fifty two companies having more than $50 \%$ foreign equity holding were removed from this list to arrive at 443 purely Indian companies for which equity holding data was available. Examination of their respective annual reports led to identification of 264 companies which have foreign subsidiaries. However, due to lack of disclosure, multi-nationality index of only 253 Indian Companies was computed and this list was used as a sample frame.

Our model for calculating Multi-nationality Index is based on adding the percentage of foreign revenue to total revenue, foreign assets to total assets, forex earning to total earnings of concerned company and then multiplying the result by the fraction of number of overseas subsidiaries of the company to the total foreign subsidiaries of all these companies together. The difference between standalone and consolidated figures was taken to represent the overseas revenues, overseas assets, overseas profits etc. against the constraint of lack of segment wise information and number of overseas employee data. Analysis of shareholding pattern in annual reports revealed percentage of foreign equity holding of these companies.

The parameters considered for computation of index of multi-nationality was based on review of previous reports such as CII- CRISIL 2006; IBEF 2008; BCG 2009 and BCG 2011. Parameters considered in some of the multinational rankings such as Fortune Global 500 (2006-2012), Forbes Global 2000(2012), Outlook Business Global 50(2008-2009) and ISB \& Fundacao Dom Cabrall Survey (2011) were also referred. The drawn list includes names of the identified Indian MNCs as revealed by above reports and further extends the list.

\subsection{Delivery and Response}

Primary data was collected through a questionnaire sent to the identified 253 companies through various modes a well as interview interface in person with senior finance executives conversant with corporate financial decisions in the international context. Responses from 51 Senior Finance Executives representing equal number of companies from the Indian corporate sector were received giving response rate of the survey to be 20.16 per cent. The response rate can be considered favorable, as compared to previous surveys; 392 firms for a 9\% return rate (Graham \& Harvey, 2001), 160 
firms for a 9.4\% return rate (Beneti, Decourt \& Terra, 2007), 313 firms for a 5\% return rate (Brounen, de Jong, \& Koedijk, 2004) and 87 firms for a $12 \%$ return rate (Bancel \& Mittoo, 2004).

\subsection{Profile of the Respondent}

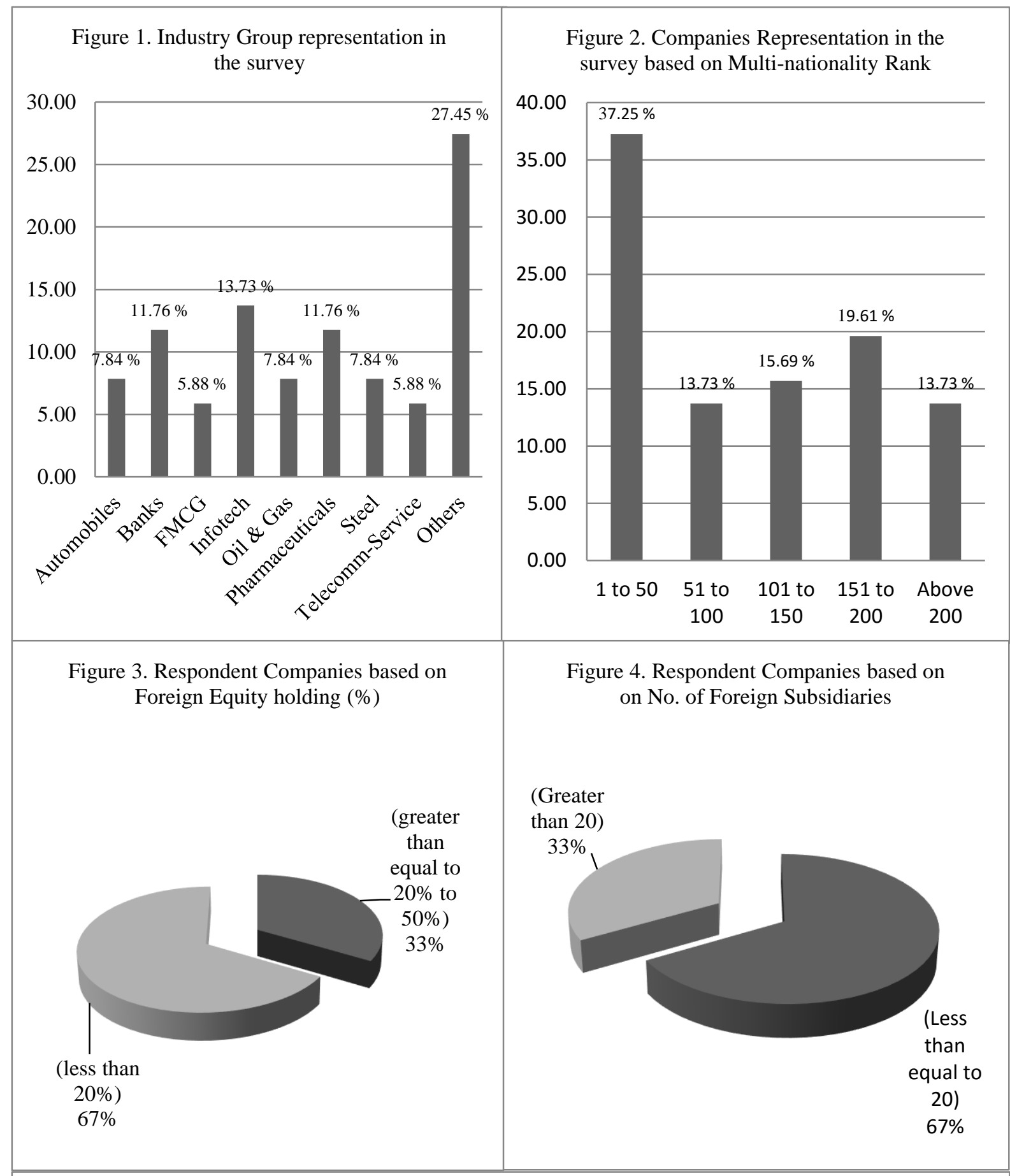

Figure 5. Respondent Companies based on Consolidated Assets

(Greater than equal to INR 500 billion) $31 \%$

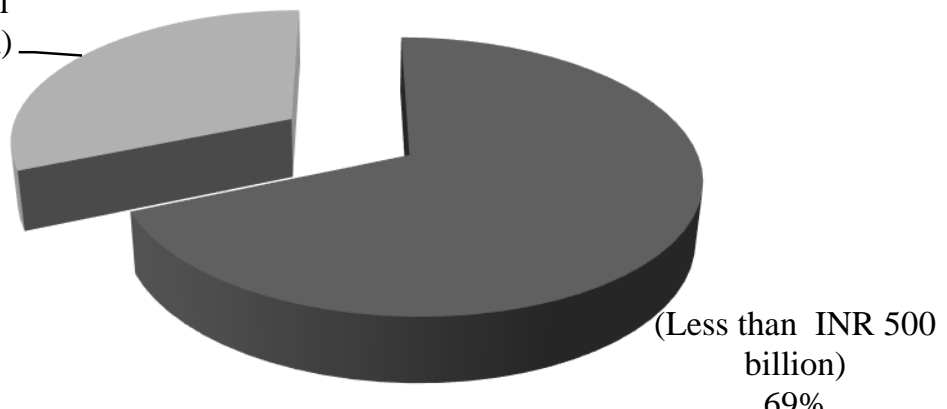

$69 \%$ 
Nineteen prominent industries are represented in the survey through 51 companies. These industries were grouped into nine different categories namely, Automobile, Infotech, Oil \& Gas, Pharmaceuticals, Steel, Banking \& Finance, Telecomm-Service, FMCG and 'Others', constituting a minimum of five companies in each industry group. The respondent companies were also grouped into size groups of consolidated assets and revenues of less than and equal to or greater than INR 500 billion. The respondents include companies with highest rank 1 to lowest rank 245. In terms of international presence through subsidiaries, 7 of the Indian MNCs companies being analyzed have more than 50 foreign subsidiaries, 9 have between 25 to 50 foreign subsidiaries and the remaining companies less than 25 subsidiaries overseas. As corporate financial policies could be impacted by the percentage of foreign equity holdings, one - third the analyzed companies have between $20 \%$ to 50\% foreign equity holdings. (Figures 1-5: Sample Characteristics)

\subsection{Techniques and Tools for Data Analysis}

SPSS 20.0 was used to analyze the primary data through proportional analysis, determining means of all responses and performing analysis of variance (ANOVA). The data is found to be normal using K-S Test ( $p>0.05)$.

\section{Analysis and Discussion}

\subsection{Investment Management Practices}

Based on ANOVA statistics appearing in Appendix 1, it is observed that there is similarity in the techniques or importance attached to various factors affecting investment decisions of Indian MNCs in their preference for use of capital budgeting techniques, method of estimating cost of equity capital, risk factors considered for adjusting the discount rates for valuation of projects, use of discount rates for evaluating a new project in the overseas market, in the preferred mode of foreign investment, and in the use of methods for valuation of merger/ acquisition/ takeover candidate. However as shown in the Table 1 derived from Appendix 1, significant differences are observed in the following aspects of investment practices:

i. The preference for IRR as a capital budgeting technique varies for companies in different industries. Companies in different Multi-nationality Index group as well as those differing in terms of number of foreign subsidiaries exhibit significant differences in their preference for use of IRR. The preference for use of Earnings multiple approach and profitability index for capital budgeting decisions depends upon the size of the company in terms of consolidated assets.

ii. Companies in different industries exhibit varying preference for use of CAPM for arriving at cost of equity.

iii. Consideration of interest rate risk for adjusting discount rate for valuation of projects is influenced by nature of industry. The size of the project for adjusting discount rate for valuation of projects as well as the practice of factoring in the discount rate for the overseas market for evaluating a new project by companies depends on the relative multi-national dimension of companies.

iv. The use of intangible assets in the valuation of mergers/ acquisition/takeover is industry specific and therefore the practice differs from industry to industry.

Table 1. Anova Statistics for Investing Decisions

\begin{tabular}{|c|c|c|c|c|c|c|c|c|c|c|c|}
\hline & \multirow{2}{*}{$\begin{array}{l}\text { Reference } \\
\text { question } \\
\text { no.in } \\
\text { Appendix 1 }\end{array}$} & \multicolumn{2}{|c|}{$\begin{array}{l}\text { Industry } \\
\text { Groups }\end{array}$} & \multicolumn{2}{|c|}{ MNI Rank } & \multicolumn{2}{|c|}{$\begin{array}{l}\% \text { of Foreign } \\
\text { Equity }\end{array}$} & \multicolumn{2}{|c|}{$\begin{array}{l}\text { Consolidated } \\
\text { Assets }\end{array}$} & \multicolumn{2}{|c|}{$\begin{array}{l}\text { Number of } \\
\text { foreign } \\
\text { subsidiaries }\end{array}$} \\
\hline & & $\mathbf{F}$ & Sig. & $\mathbf{F}$ & Sig. & $\mathbf{F}$ & Sig. & $\mathbf{F}$ & Sig. & $\mathbf{F}$ & Sig. \\
\hline 1(a) Internal rate of return & 1(b) & 4.055 & .001 & 3.383 & .017 & .000 & .995 & .285 & .596 & 4.327 & .043 \\
\hline $\begin{array}{ll}\text { 1(b)Earnings multiple } \\
\text { approach }\end{array}$ & $1(\mathrm{~d})$ & 1.761 & .115 & .758 & .559 & .361 & .551 & 9.571 & .003 & .475 & .494 \\
\hline 1(c)Profitability index & $1(\mathrm{~h})$ & .411 & .907 & .476 & .753 & .044 & .834 & 4.671 & .036 & 1.534 & .222 \\
\hline $\begin{array}{l}\text { 2(a) Using the capital asset } \\
\text { Pricing model (CAPM, the } \\
\text { "beta" approach) }\end{array}$ & 2(b) & 2.709 & .020 & .317 & .865 & 3.143 & .084 & .680 & .414 & .140 & .710 \\
\hline $\begin{array}{l}\text { 2(b) Using the CAPM but } \\
\text { including some "risk } \\
\text { factors" }\end{array}$ & $2(\mathrm{c})$ & 2.296 & .042 & .633 & .642 & 2.229 & .143 & .730 & .398 & 1.460 & .234 \\
\hline $\begin{array}{l}\text { 3(a) Interest rate risk } \\
\text { (change in general level of } \\
\text { interest rates) }\end{array}$ & $3(\mathrm{~b})$ & 2.589 & .023 & .036 & .997 & .323 & .572 & .740 & .394 & .216 & .644 \\
\hline
\end{tabular}




\begin{tabular}{|c|c|c|c|c|c|c|c|c|c|c|c|}
\hline 3(b)Commodity price risk & $3(\mathrm{e})$ & 975 & .469 & 2.562 & .050 & .370 & .546 & .038 & .846 & 1.987 & .165 \\
\hline $\begin{array}{l}3 \text { (c)Size (small firm being } \\
\text { riskier) }\end{array}$ & $3(\mathrm{~h})$ & 1.665 & 139 & 3.021 & .028 & .794 & .378 & 1.943 & .170 & 2.778 & .102 \\
\hline $\begin{array}{l}\text { 4(a)The discount rate for the } \\
\text { overseas market (country } \\
\text { discount rate) }\end{array}$ & 4(b) & 1.059 & .412 & 3.472 & .015 & .000 & 1.000 & .000 & 1.000 & 3.077 & .086 \\
\hline $\begin{array}{l}\text { 5(a) Market Based-Market } \\
\text { multiples for comparable } \\
\text { company for unlisted } \\
\text { companies }\end{array}$ & 7(b2) & .400 & .913 & 5.023 & .002 & .244 & .624 & .091 & .764 & 2.048 & .160 \\
\hline $\begin{array}{l}5 \text { (b) Asset Based Intangible } \\
\text { asset valuation }\end{array}$ & 7(c2) & 2.542 & .027 & 1.088 & .376 & 201 & 656 & 1.294 & 262 & 1.388 & .245 \\
\hline
\end{tabular}

\subsection{Financing Practices}

Based on the ANOVA statistics appearing in the Appendix 2, it is observed that there is similarity in the practices as indicated by preference or importance attached to various factors affecting financing decisions of Indian MNCs such as appropriate amount of debt, foreign debt, equity capital, convertible debt, choice of debt policy, choice of markets to raise long -term funds and choice of preferred instrument to raise long-term or short-term debt. An analysis of Table 2 extracted from Appendix 2 reveals the following significant differences in financing aspects:

The relative importance attached to tax advantage of interest deductibility while determining appropriated amount of debt differs depending upon the geographical spread and presence through number of subsidiaries. Differences are also visible in the consideration of potential cost of bankruptcy/distress as an important factor affecting appropriate amount of debt as influenced by degree of multi-nationality indicated by MNI rank.

i. Companies differing in terms of number of foreign subsidiaries exhibit varying importance to foreign regulations when considering issuing debt abroad. The borrowings by Indian MNC's tend to be more from domestic markets similar to other emerging markets like Brazil. Rossi, (2009) indicated insignificant impact of asset based on borrowings due to low enforceability. Companies having varying percentages of foreign equity holdings also consider foreign interest rates as compared to domestic interest rates while taking decision about issuing foreign debt.

ii. While considering decision about issuing equity capital, companies grouped by consolidated assets differ in considering equity as a least risky source of funds. Providing shares to employees through bonus or stock option as a factor in decision for issuing equity capital varies with size of the company in terms of consolidated assets. Issuing equity with the motive of diluting shareholding of other shareholders varies with the number of foreign subsidiaries of an Indian MNCs.

iii. While determining debt policy, companies in different industries as well as in different MNI group differ in the considering the use of debt when the equity is undervalued by the market or due to delay in retiring debt because of recapitalization costs \& fees.

iv. Differences are observed in considering convertibles debt to be less expensive than straight debt by companies in different MNI groups and consolidated assets groups. Companies grouped by consolidated assets show differences in attributing the successful use of convertibles by other firms in the industry as a significant factor in the issue of convertible debt. The flexibility to "call" or force convertible debt whenever required is also a significant factor to issue convertible debt perceived differently due to industry representation. Companies belonging to different MNI as well as different consolidated assets group differ in considering attracting investors unsure about the riskiness of the company while issuing convertible debt.

v. Issuing short- term debt in anticipation of long term market interest rates to decline and preference for shortterm debt in order to capture returns from new projects by shareholders instead of committing interest payments to debt holders is significantly influenced by industry characteristics.

vi. Companies in different MNI rank groups show marked difference in the relative preference for host country market for raising loan- term funds.

vii. There is significant difference in the relative preference of instruments for raising long term funds. Differences are observed in the preference of equity by differently MNI ranked companies, ECBs due to industry representation and IDR due to their number of foreign subsidiaries.

viii. Differences are also observed in the relative preference of instruments for raising short-term funds. Companies in different industries and falling in different consolidated assets group differ in their preference for commercial paper. Preference for issuing short -term bank loans in India varies with industry. Companies differing in terms of number of foreign subsidiaries also exhibit differences in their preference for advance 
payments from customers and associates in India as well as overseas as an instrument for raising short -term funds.

Table 2. Anova Statistics for Financing Decisions

\begin{tabular}{|c|c|c|c|c|c|c|c|c|c|c|c|}
\hline & \multirow{2}{*}{$\begin{array}{l}\text { Reference } \\
\text { question } \\
\text { no. in } \\
\text { Appendix } \\
2\end{array}$} & \multicolumn{2}{|c|}{$\begin{array}{l}\text { Industry } \\
\text { Groups }\end{array}$} & \multicolumn{2}{|c|}{ MNI Rank } & \multicolumn{2}{|c|}{$\begin{array}{l}\% \quad \text { of } \\
\text { Foreign } \\
\text { Equity }\end{array}$} & \multicolumn{2}{|c|}{$\begin{array}{l}\text { Consolidated } \\
\text { Assets }\end{array}$} & \multicolumn{2}{|c|}{$\begin{array}{l}\text { Number of foreign } \\
\text { subsidiaries }\end{array}$} \\
\hline & & $\mathrm{F}$ & Sig. & $\mathrm{F}$ & Sig. & $\mathrm{F}$ & Sig. & $\mathrm{F}$ & Sig. & $\mathrm{F}$ & Sig. \\
\hline $\begin{array}{l}\text { 1(a)The potential costs of } \\
\text { bankruptcy, near- } \\
\text { bankruptcy or distress }\end{array}$ & $8(b)$ & 1.445 & .210 & 2.683 & .044 & .186 & .668 & .053 & .818 & 3.880 & .050 \\
\hline $\begin{array}{l}\text { 1(b)We limit debt so our } \\
\text { customers/suppliers are } \\
\text { not worried about our } \\
\text { firm going out of } \\
\text { business }\end{array}$ & 8(i) & .945 & .492 & .572 & .684 & 9.167 & .004 & .120 & .730 & .005 & .941 \\
\hline $\begin{array}{l}\text { 2(a)Foreign regulations } \\
\text { require us to issue debt } \\
\text { abroad }\end{array}$ & $9(d)$ & 1.248 & .301 & 1.187 & .332 & 1.019 & .319 & .403 & .529 & 5.887 & .020 \\
\hline $\begin{array}{l}\text { 2(b)Foreign interest rates } \\
\text { may be lower than } \\
\text { domestic interest }\end{array}$ & $9(e)$ & 2.018 & .073 & .503 & .734 & 4.837 & .033 & .000 & .988 & .016 & .899 \\
\hline $\begin{array}{l}3 \text { (a) If our equity price } \\
\text { has recently risen, the } \\
\text { price at which we can } \\
\text { sell is "high" }\end{array}$ & $10(a)$ & 2.218 & .050 & .576 & .682 & .004 & .953 & 2.880 & .097 & 1.415 & .241 \\
\hline $\begin{array}{l}\text { 3(b)Equity is our "least } \\
\text { risky" source of funds }\end{array}$ & $10(b)$ & 1.907 & .089 & 1.043 & .397 & .031 & .860 & 5.404 & .025 & .034 & .856 \\
\hline $\begin{array}{l}\text { 3(c)Providing shares to } \\
\text { employees bonus/stock } \\
\text { option plans }\end{array}$ & $10(\mathrm{c})$ & 1.258 & .295 & 2.157 & .092 & .518 & .476 & 5.149 & .028 & .034 & .854 \\
\hline $\begin{array}{l}3(\mathrm{~d}) \text { Diluting the holding } \\
\text { of certain share holders }\end{array}$ & $10(\mathrm{j})$ & 1.325 & .263 & 1.271 & .298 & .389 & .536 & .620 & .435 & 7.793 & .008 \\
\hline $\begin{array}{l}\text { 4(a)We use debt when } \\
\text { our equity is undervalued } \\
\text { by the market }\end{array}$ & $11(\mathrm{~d})$ & 2.523 & .026 & .667 & .618 & .645 & .426 & .724 & .399 & 1.285 & .263 \\
\hline $\begin{array}{l}4(\mathrm{~b}) \mathrm{We} \text { delay retiring } \\
\text { debt because of } \\
\text { recapitalization costs \& } \\
\text { fees }\end{array}$ & $11(f)$ & 2.639 & .021 & 4.352 & .005 & .610 & .439 & 1.089 & .302 & .115 & .736 \\
\hline $\begin{array}{l}5 \text { (a)Convertibles are less } \\
\text { expensive than straight } \\
\text { debt }\end{array}$ & $12(\mathrm{c})$ & .826 & .586 & 2.955 & .032 & .782 & .382 & 7.392 & .010 & .154 & .697 \\
\hline $\begin{array}{l}\text { 5(b)Other firms in our } \\
\text { industry successfully use } \\
\text { convertibles }\end{array}$ & $12(d)$ & 1.953 & .084 & 1.456 & .235 & .183 & .671 & 9.195 & .004 & .065 & .800 \\
\hline $\begin{array}{l}5(\mathrm{c}) \text { Ability to "call" or } \\
\text { force conversion of } \\
\text { convertible debt if/when } \\
\text { we need to }\end{array}$ & $12(\mathrm{~g})$ & 2.627 & .024 & 1.198 & .328 & 2.023 & .163 & 3.186 & .082 & .000 & 1.000 \\
\hline
\end{tabular}




\begin{tabular}{lllllllllllllllll}
\hline 5(d)To attract investors & $12(\mathrm{~h})$ & & 1.633 & .152 & 3.289 & .021 & .000 & .990 & 4.999 & .031 & .007 & .933
\end{tabular}

unsure about the

riskiness of our company

\begin{tabular}{|c|c|c|c|c|c|c|c|c|c|c|c|}
\hline $\begin{array}{l}6 \text { (a) We issue short-term } \\
\text { when short-term interest } \\
\text { rates our low compared } \\
\text { to long-term rates }\end{array}$ & 13(a) & .985 & .462 & .448 & .773 & .058 & .811 & 6.884 & .012 & .427 & .517 \\
\hline $\begin{array}{l}6(\mathrm{~b}) \text { We issue short-term } \\
\text { when we are waiting for } \\
\text { the long-term market } \\
\text { interest rates to decline }\end{array}$ & $13(c)$ & 3.391 & .005 & .836 & .510 & .965 & .331 & 1.335 & .254 & .295 & .590 \\
\hline $\begin{array}{l}6(\mathrm{c}) \text { We borrow short- } \\
\text { term so that returns from } \\
\text { new projects can be } \\
\text { captured more fully by } \\
\text { shareholders rather that } \\
\text { committing to pay long- } \\
\text { term profits as interest to } \\
\text { debt holders }\end{array}$ & $13(d)$ & 2.306 & .041 & .371 & .828 & .894 & .349 & .140 & .710 & .045 & .833 \\
\hline 7(a)Host country markets & $14(c)$ & .917 & .525 & 3.529 & .023 & .212 & .649 & .026 & .874 & N.A. & N.A. \\
\hline 8(a) Equity & $16(a)$ & .654 & .727 & 2.684 & .044 & .767 & .386 & .046 & .832 & 2.438 & .125 \\
\hline 8(b)IDR & $16(h)$ & .635 & .743 & 1.078 & .382 & 1.041 & .314 & .092 & .763 & 4.145 & .049 \\
\hline 8(c)Interest free loans & $16(j)$ & 2.029 & .069 & .161 & .957 & 7.818 & .008 & .015 & .903 & .846 & .363 \\
\hline 8(d)others & $16(1)$ & 7.520 & .037 & .346 & .794 & .139 & .719 & .211 & .659 & .000 & 1.000 \\
\hline $\begin{array}{l}\text { 9(a) Issue of Commercial } \\
\text { paper in India }\end{array}$ & 17(a) & 3.764 & .003 & 1.972 & .117 & .149 & .701 & 5.004 & .030 & .149 & .701 \\
\hline $\begin{array}{l}\text { 9(b)Short term- bank } \\
\text { loans in India }\end{array}$ & $17(c)$ & 2.287 & .042 & 2.454 & .061 & .358 & .553 & .001 & .975 & 2.062 & .158 \\
\hline $\begin{array}{l}\text { 9(c)Short term bank } \\
\text { loans overseas }\end{array}$ & $17(d)$ & 2.005 & .073 & 1.750 & .158 & 4.032 & .050 & .478 & .493 & 2.441 & .125 \\
\hline $\begin{array}{l}\text { 9(d)Factoring receivables } \\
\text { in India }\end{array}$ & $17(\mathrm{~g})$ & 1.009 & .447 & 1.336 & .273 & 1.376 & .247 & .089 & .767 & 6.434 & .015 \\
\hline $\begin{array}{l}\text { 9(e)Advance payments } \\
\text { from customers and } \\
\text { associates overseas }\end{array}$ & $17(\mathrm{k})$ & .533 & .824 & 2.050 & .106 & .059 & .809 & 1.357 & .250 & 6.544 & .014 \\
\hline
\end{tabular}

\subsection{Management Control Practices}

ANOVA statistics appearing in the Appendix 3provides evidence of similarities and differences in management control practices of Indian MNCs as indicated by relative importance of factors considered for financial performance measurements and the methods followed for transfer pricing. However as can be observed in Table 3, significant differences are observed in the following management control practices:

i. Companies falling in different consolidated asset size groups exhibit dissimilarities in relative importance to separate ROI for each country operations'. The use of 'Net cash flow' as a financial performance measure differs depending upon number of foreign subsidiaries. The industry representation also affects the use of 'free cash flow' as a measure for financial performance.

ii. The use of 'cost plus pricing' and 'At arm's length' methods for transfer pricing varies depending upon the number of foreign subsidiaries of Indian MNC. 
Table 3. Anova Statistics for Management Control Decisions

\begin{tabular}{|c|c|c|c|c|c|c|c|c|c|c|c|}
\hline & \multirow[t]{2}{*}{$\begin{array}{l}\text { Reference } \\
\text { question no. in } \\
\text { Appendix } 4\end{array}$} & \multicolumn{2}{|c|}{ Industry Groups } & \multicolumn{2}{|c|}{ MNI Rank } & \multicolumn{2}{|c|}{$\begin{array}{l}\% \\
\text { Foreign } \\
\text { Equity }\end{array}$} & \multicolumn{2}{|c|}{$\begin{array}{l}\text { Consolidated } \\
\text { Assets }\end{array}$} & \multicolumn{2}{|c|}{$\begin{array}{l}\text { Number of } \\
\text { foreign } \\
\text { subsidiaries }\end{array}$} \\
\hline & & $\mathrm{F}$ & Sig. & $\mathrm{F}$ & Sig. & $\mathrm{F}$ & Sig. & $\mathrm{F}$ & Sig. & $\mathrm{F}$ & Sig. \\
\hline $\begin{array}{l}\text { 1(a)Separate ROI } \\
\text { for each country } \\
\text { operation }\end{array}$ & 21(b) & 1.185 & .334 & .462 & .763 & 1.152 & .289 & 4.156 & .048 & .015 & .902 \\
\hline 1(b)Net Cash flow & $21(d)$ & 1.586 & .162 & 1.192 & .329 & .504 & .482 & .063 & .802 & 4.666 & .036 \\
\hline 1(c)Free cash flow & $21(\mathrm{e})$ & 2.871 & .014 & 2.481 & .059 & .075 & .785 & .245 & .623 & 2.751 & .104 \\
\hline $\begin{array}{ll}\text { (a) Cost plus } \\
\text { pricing }\end{array}$ & $22(a)$ & .818 & .592 & .782 & .544 & 1.243 & .271 & .041 & .840 & 5.310 & .026 \\
\hline 2(b)At arm's length & $22(d)$ & 1.100 & .386 & .710 & .590 & .040 & .843 & .002 & .969 & 5.795 & .020 \\
\hline
\end{tabular}

\subsection{Dividend Practices}

Based on the ANOVA statistics in Table 4it is observed that there is similarity in the dividend decisions of Indian MNCs indicated by the extent of repatriation of foreign earnings, preference for type of dividend and dividend policy irrespective of their industry representation, multi-nationality rankings, consolidated assets, foreign equity holding percentage and number of foreign subsidiaries.

However as can be observed from Table 4 derived from Appendix 4, significant differences are observed in the following dividend related practices:

i. There is significant difference in the extent of repatriation of foreign earnings on the basis of differences in the industry representation.

ii. There is significance difference in the dividend policies on the basis of differences in the MNI ranking.

Table 4. Anova Statistics for Dividend Decisions

\begin{tabular}{|c|c|c|c|c|c|c|c|c|c|c|c|}
\hline & \multirow{2}{*}{$\begin{array}{l}\text { Reference } \\
\text { question no. } \\
\text { in Appendix } \\
3\end{array}$} & \multicolumn{2}{|c|}{$\begin{array}{l}\text { Industry } \\
\text { Groups }\end{array}$} & \multicolumn{2}{|c|}{ MNI Rank } & \multicolumn{2}{|c|}{$\begin{array}{l}\% \text { of Foreign } \\
\text { Equity }\end{array}$} & \multicolumn{2}{|c|}{$\begin{array}{l}\text { Consolidated } \\
\text { Assets }\end{array}$} & \multicolumn{2}{|c|}{$\begin{array}{l}\text { Number of } \\
\text { foreign } \\
\text { subsidiaries }\end{array}$} \\
\hline & & $\mathrm{F}$ & Sig. & $\mathrm{F}$ & Sig. & $\mathrm{F}$ & Sig. & $\mathrm{F}$ & Sig. & $\mathrm{F}$ & Sig. \\
\hline $\begin{array}{l}\text { 1. To what extent co. } \\
\text { remit foreign earnings }\end{array}$ & 18 & 2.241 & .049 & .776 & .548 & 1.128 & .294 & 1.648 & .206 & .808 & .374 \\
\hline $\begin{array}{l}\text { 2. Characterization of } \\
\text { co.'s dividend policy }\end{array}$ & 20 & 1.861 & .097 & 2.810 & .038 & .394 & .533 & 1.183 & .283 & N.A. & N.A. \\
\hline
\end{tabular}

\section{Findings}

The study clearly brings out that financial behaviour of Indian MNCs is affected by Industry, number of subsidiaries, foreign equity holding and size of the company in terms of assets.

\subsection{Industry Affects}

The differences in practices attributable to industry affects is seen in the use of IRR as a capital budgeting technique, preference for the use of CAPM for arriving at cost of capital, considering use of debt in capital structure when equity is undervalued by market or there is delay in retirement of debt for the reasons of recapitalization costs. The industry-wise differences are also significant in relative importance to factors affecting borrowings such as flexibility to call or force convertible debt, preference for issue of short-term debt in anticipation for long-term market rates to decline, preference for borrowing short-term loan to capture returns for shareholders instead of committing interest to long-term debt providers. Industry characteristics also affect the relative importance to ECB and short- term bank loan as instruments to raise funds. Industry also affects the free cash flow available and its use for management control. It is seen that the extent of repatriation of foreign earnings as a factor in dividend decision affecting retention policy to finance future growth and meet regulatory compliances is also shaped by nature of industry.

\subsection{Number of Foreign Subsidiaries}

The number of foreign subsidiaries not only points to ownership structures, corporate parent chain but also geographical spread of MNCs influencing financial behavior. The differences in practices can be seen in consideration of IRR as a capital budgeting technique due to variety of adjustments required to arrive at cash flows. The relative importance 
attached to tax advantage of interest deductibility while determining appropriate amount of debt as well as considering issuing debt abroad amongst other factors depends on host country regulatory requirements. Significant difference in the relative preference of instruments for raising long term funds through IDR are observed explainable due to location factors, ease of market access and ability to raise funds. The relative preference for issuing equity with the motive of diluting shareholding of other shareholders is also influenced by number of foreign subsidiaries of an Indian MNCs appears to be due to reasons of corporate control. In the area of working capital management marked differences persist between companies with different number of subsidiaries in according preference for advance payments from customers and associates in India as well as overseas as an instrument for raising short -term funds.

\subsection{Size}

The differences in the financial behaviour due to size have been confirmed by various studies. The results of this study also suggest that Indian MNCs in different asset size groups differ in their preference for use of Earnings multiple approach and profitability index for capital budgeting decisions. The size of the company in terms of assets is a factor in considering issuing equity capital, and also regarding it as a least risky source of funds. This may be due the need to maintain a target debt to equity ratio and the magnitude of owners funds needed to fund expansion needs. Companies in different asset size groups also differ in considering providing shares to employees through bonus or stock option while issuing equity capital. They also exhibit varying behaviour in considering convertibles debt to be less expensive than straight debt depending upon their own mix of funds in capital structure and asset liability match. They also show differences in attributing the successful use of convertibles by other firms in the industry as a significant factor in the issue of convertible debt as well as in their preference for issue of commercial paper.

\subsection{Foreign Equity Affects}

The amount of foreign equity in capital structure of Indian MNCs affects the cost of funds. The survey results point out companies having varying percentages of foreign equity holdings also consider foreign interest rates as compared to domestic interest rates while taking decision about issuing foreign debt.

\subsection{Multi-nationality Affects}

Indian MNCs grouped in ranks as per multi- nationality index show difference in preference for use of IRR as well as in the practice of factoring the discount rate for the overseas market for evaluating a new project in their investment decisions. The degree of multi- nationality also affects differences in their consideration for issue of debt when equity is undervalued or due to delays in retirement of debt taking into account recapitalization costs and fees. Consideration of potential bankruptcy costs from use of debt, viewing convertible debt cheaper than straight debt, relative preference for raising long-term funds in host country market as well as preference for raising equity over debt is influenced by degree of multi-nationality which also significantly affects the dividend policies of these Indian MNCs.

\section{Conclusion}

The results support previous studies in corporate financial behavior of companies exhibiting differences in their practices due to their size and industry characteristics. It further extends to identifying differences in their behavior attributable to differences in multi-nationality rank, number of foreign subsidiaries and foreign equity holdings. This study contributes to bring out the significant differences in important aspects in investing, financing, dividend and management control practices of Indian MNCs arising due to differences in contextual factors and their make- up. However, the inferences need to be drawn in the light of the fact that this research is an exploratory attempt to understand the corporate financial behavior and practices which take into account number of factors and variables. Therefore, the statistical / quantitative data used for drawing inferences need to incorporate qualitative aspects of decision making in the real world subject to situations and conditions. The similarities and differences brought out above helps to explain the nature of factors and considerations involved in corporate financial practices of Indian MNCs depending on their makeup, characteristics and contextual factors.

\section{References}

Adler, D. (2004). A Behavioral Theory of Corporate Finance. Strategy+Business, 34. [Online] Available: http://www.strategy-business.com/article/04113?gko=78b39\&tid=27782251. [In text Citation: Adler, 2004]

Anand, M. (2002). Corporate Finance Practices in India: A Survey, Vikalpa, 27(4), 29-56 . [Online] Available: http://www.vikalpa.com/pdf/articles/2002/2002_oct_dec_29_56.pdf [In text Citation: Anand, 2002]

Balbinotti , M. A. A.., Benetti , Cristiane., Terra, P. R. S. Translation and Validation of the Graham-Harvey Survey for the Brazilian Context. International Journal of Managerial Finance, 3, 26-48.

Bancel, F., \& Mitto, U.R. (2004). Cross-Country Determinants of Capital Structure Choice: a Survey of European Firms. Financial Management, 33, 103-132. [Online] Available: https://books.google.co.in/books?id=Et3czch2uJUC\&pg =PA488\&lpg=PA488\&dq. [In text Citation: Bancel \& Mitto, 2004]

Brounen, D., de Jong, A., \& Koedijk, K. (2004). Corporate Finance in Europe: Confronting Theory with Practice. Financial Management, 34, [Online] 71-101. Available: http://repub.eur.nl/pub/1111/ERS\%202004\%20002\%20F\&A.pdf. [In text Citation: Brounen, de Jong, \& Koedijk, 2004] 
BCG Report (2009). Report on The 2009 BCG 100 New Global Challengers - How Companies from Rapidly Developing Economies are Contending for Global Leadership. Available: http://www.bcgindia.com/documents/ file20519.pdf. [In text Citation: BCG (2009)]

BCG Report (2011),. BCG Global Challengers:Companies on the Move- Rising Stars from Rapidly Developing Economies Reshaping Global Industries. [Online] Available: http://www.bcgindia.com/ documents/file70055.pdf. [In text Citation: BCG 2011]

CII - CRISIL (2006). A Report on Creating the Indian MNC, CRISIL Centre for Economic Research. [Online] Available : http://www.ibef.org/download/CII_Report_Outward_FDI_2006_270906.pdf. [In text Citation: CII-CRISIL, 2006]

Cohen, G., \& Yagil, J. (2007). A Multinational Survey of corporate Financial Policies. Journal of Applied Finance, 17(1), 57-69. [In text Citation: Cohen \& Yagil, 2007]

Cohen, G., \& Yagil, J. (2010). Sectorial Differences in Corporate Financial Behaviour: An International Survey. European Journal of Finance, 16:3, 245-262

Cronqvist Henrik, Makhija, Anil K, and Yonker, Scott E.(2012). Behavioral Consistency in Corporate Finance: CEO Personnel and Corporate Leverage. Journal of Financial Economics, 103 (1), 20-40. [Online] Available: http://www.sciencedirect.com/science/article/pii/S0304405X11001851. [In text Citation: Cronqvist, et al., 2012 ]

ETIG (2011). [Online] Available : http://etintelligence.com/etig/et500/et500Ranking.jsp

Forbes Global 2000 (2012). Methodology: How we crunch the numbers - Scott de Carlo, Forbes Staff . Available: http://www.forbes.com/sites/scottdecarlo/2012/04/18/methodology-how-we-crunch-the-numbers/. [In text Citation: Forbes Global 2000 (2012)]

Fortune Global 500 (2006-2012). Fortune magazine's issue July 24, 2006; July 23,2007; July 21,2008; July 20,2009; July 26, 2010; July 25, 2011 and July 23, 2012. [Online] Available :http://money.cnn.com/magazines/fortune/global500/2012/countries/India.html?iid=smlrr and http://money.cnn.com/magazines/fortune/global500/2011/countries/India.html. [In text Citation: Fortune Global 500 (2006-2012)]

F. Rossi \& RJ Cebula (2015). Stock Market Reactions to Announcements of Board of Director Appointments: Evidence from Italy. Applied Economics, 47 (20), 2012-2118. [In text Citation: Rossi and Cebula, 2015

Graham, J.R., \& Harvey, C.R. (2001). The Theory and Practice of Corporate Finance: Evidence from the Field. Journal of Financial Economics, 60, 187-243. [Online] Available : http://www.sciencedirect.com/science/article/B6VBX433W7FJ-2/2/335ca4162c5ab52cc8e08b52d0cad063 . [In text Citation: Graham \& Harvey, 2001]

IBEF (2006). Going Global: Indian Multinationals, India. [Online] Available: http://www.indiabrandequityfund.org/artdisplat.aspx?cat_id=410\&art_id=137257 (October, 2006).

ISB, Hyderabad \& Fundacao Dom Cabrall (Business School) Brazil survey (2009). Available: http://ccsi.columbia.edu/files/2013/10/India_2009.pdf.[In text Citation: ISB \& Fundacao Dom Cabrall, 2009]

Mattana, P., Petroni, F., \& Rossi, S.P.S. (2014). A Test for the Too-Big-to-Fail Hypothesis for European Banks during the Financial Crisis. Applied Economics., 47, 4. [In text Citation: Mattana et al, 2014]

Outlook Business Global 50 (2008-2009). Outlook Business Magazines different issues. [In text citation: Outlook Business Global 50 (2008-2009)]

PWC Report (2014). Trends, Shaping, Governance and the Board of the Future, Annual Corporate Director's Survey. 2014. [Online] Available at http://www.pwc.com/us/en/corporate-governance/annual-corporate -directors-survey/assets/ annual-corporate-directtor-survey-full-report-pwc.pdf[In text Citation: PwC, 2014]

Rossi, J.L. Junior (2009). Corporate Financial Policies and the Exchange Rate Regime: Evidence from Brazil. Emerging Markets Review. 10.(4) , 279-295. [In text Citation: Rossi, 2009]

Saha, A. (2012). The Practice of Corporate Finance in India: Survey of CFOs, 2012. 2nd International Conference on Economics and Finance Research; IPEDR (ISSN: 2010-4626), 15 (2011) IACSIT Press, Singapore. [Online] Available :http://www.ipedr.com/ and https://www.academia.edu/Documents/in/Capital_Structure? page=7. [In text Citation: Saha, 2012]

Sharma, J.K \& Pandey,V.di (2015). Dividend Signaling and Market Efficiency in Emerging Economy: A Study of Indian Stock Market. International Journal of Finance and Accounting Studies , 2(2) , [In text Citation: Sharma \& Pandey (2015)]

Thompson, A.A.., \& Strickland, A.J., Gamble, J.E., Jain, A.K., (2003). Strategic Management - Concepts and Cases. (14th ed, p.56). McGraw Hill., (Chapter 6). 
Appendix 1: Anova Statistics for Investing Decisions

\begin{tabular}{|c|c|c|c|c|c|c|c|c|c|c|c|c|}
\hline \multicolumn{13}{|c|}{ Appendix 1: Anova Statistics for Investing Decisions } \\
\hline & \multirow{2}{*}{$\begin{array}{l}\% \text { of always or almost of the } \\
\text { times }\end{array}$} & \multirow{2}{*}{ Mean } & \multicolumn{2}{|c|}{$\begin{array}{l}\text { Industry } \\
\text { Groups }\end{array}$} & \multicolumn{2}{|c|}{ MNI Rank } & \multicolumn{2}{|c|}{$\begin{array}{l}\% \text { of Foreign } \\
\text { Equity }\end{array}$} & \multicolumn{2}{|c|}{$\begin{array}{l}\text { Consolidated } \\
\text { Assets }\end{array}$} & \multicolumn{2}{|c|}{$\begin{array}{l}\text { Number of foreign } \\
\text { subsidiaries }\end{array}$} \\
\hline & & & $\mathrm{F}$ & Sig. & $\mathrm{F}$ & Sig. & $\mathrm{F}$ & Sig. & $\mathrm{F}$ & Sig. & $\mathrm{F}$ & Sig. \\
\hline \multicolumn{13}{|c|}{ 1.Preferred Capital Budgeting Technique } \\
\hline 1(a) Net present value & 86.0 & 3.28 & 1.328 & .257 & 1.694 & .168 & .930 & .340 & .091 & .764 & .417 & .522 \\
\hline 1(b)Internal rate of return & 83.7 & 3.37 & 4.055 & .001 & 3.383 & .017 & .000 & .995 & .285 & .596 & 4.327 & .043 \\
\hline 1(c)Hurdle rate & 47.9 & 2.44 & 1.529 & .179 & 1.137 & .352 & 1.995 & .165 & .780 & .382 & .118 & .733 \\
\hline 1(d)Earnings multiple approach & 45.8 & 2.31 & 1.761 & .115 & .758 & .559 & .361 & .551 & 9.571 & .003 & .475 & .494 \\
\hline 1(e)Adjusted present value & 62.5 & 2.60 & 1.079 & .397 & .552 & .699 & .001 & .977 & .961 & .332 & 1.951 & .169 \\
\hline 1(f)Payback period & 75.5 & 3.02 & .565 & .800 & .361 & .835 & .881 & .353 & 1.635 & .207 & 2.251 & .140 \\
\hline 1(g)Discounted payback period & 61.2 & 2.63 & 1.046 & .419 & 1.890 & .129 & .021 & .887 & 1.251 & .269 & 1.034 & .314 \\
\hline 1(h)Profitability index & 57.1 & 2.49 & .411 & .907 & .476 & .753 & .044 & .834 & 4.671 & .036 & 1.534 & .222 \\
\hline 1(i)Accounting rate of return (or book rate of return on assets) & 41.7 & 2.10 & .448 & .885 & .241 & .913 & .042 & .838 & .359 & .552 & 1.029 & .316 \\
\hline 1(j)Sensitivity analysis & 67.3 & 2.73 & .479 & .864 & .438 & .780 & .236 & .629 & .000 & .996 & .370 & .546 \\
\hline 1(k)Value-at risk or other simulation analysis & 57.1 & 2.59 & .398 & .915 & .616 & .653 & .004 & .952 & .243 & .624 & 1.085 & .303 \\
\hline 1(1)We incorporate the "real options" of a project when evaluating it & 36.2 & 2.00 & .306 & .959 & 1.343 & .270 & .946 & .336 & .253 & .617 & .968 & .330 \\
\hline \multicolumn{13}{|c|}{ 2. Methods of Arriving at cost of Equity Capital } \\
\hline 2(a) With average historical return on common stock & 65.9 & 2.89 & .641 & .738 & .591 & .671 & .000 & .991 & .195 & .661 & .578 & .451 \\
\hline 2(b) Using the capital asset Pricing model (CAPM, the "beta" approach) & 52.3 & 2.36 & 2.709 & .020 & .317 & .865 & 3.143 & .084 & .680 & .414 & .140 & .710 \\
\hline 2(c) Using the CAPM but including some "risk factors" & 53.3 & 2.60 & 2.296 & .042 & .633 & .642 & 2.229 & .143 & .730 & .398 & 1.460 & .234 \\
\hline 2(d) Whatever our investors say they require & 40.9 & 2.32 & 1.566 & .171 & 1.082 & .379 & .854 & .361 & 1.098 & .301 & 1.336 & .254 \\
\hline 2(e) By regulatory decisions & 65.1 & 2.67 & .512 & .839 & 1.958 & .121 & .481 & .492 & 1.765 & .191 & 1.101 & .300 \\
\hline $\begin{array}{l}\text { 2(f)Back out from discounted dividend/earnings model, e.g. Price= Div/(cost of cap. } \\
\text { - growth) }\end{array}$ & 44.2 & 2.26 & .420 & .901 & 1.038 & .401 & 2.219 & .144 & .000 & .984 & .062 & .805 \\
\hline \multicolumn{13}{|c|}{ 3. Risk factors for adjusting Discount Rates } \\
\hline 3( a)Risk of unexpected inflation & 68.8 & 2.96 & 1.546 & .173 & .563 & .691 & .166 & .686 & .401 & .530 & 1.822 & .184 \\
\hline 3(b)Interest rate risk (change in general level of interest rates) & 83.3 & 3.33 & 2.589 & .023 & .036 & .997 & .323 & .572 & .740 & .394 & .216 & .644 \\
\hline 3(c)Term structure risk (change in the long term Vs. short term interest rates) & 76.6 & 3.06 & 1.768 & .114 & .395 & .811 & .131 & .719 & 1.008 & .321 & 2.353 & .132 \\
\hline 3(d)GDP or business cycle risk & 72.3 & 2.98 & 1.382 & .236 & .894 & .476 & 2.216 & .144 & .616 & .437 & .140 & .710 \\
\hline 3(e)Commodity price risk & 66.7 & 2.77 & .975 & .469 & 2.562 & .050 & .370 & .546 & .038 & .846 & 1.987 & .165 \\
\hline 3(f)Foreign exchange risk & 82.6 & 3.39 & .978 & .468 & .309 & .870 & .000 & .989 & 3.314 & .076 & .013 & .908 \\
\hline 3(g)Distress risk (probability of bankruptcy) & 41.7 & 2.23 & 1.057 & .412 & .267 & .898 & .021 & .885 & .118 & .733 & .452 & .505 \\
\hline 3(h)Size (small firm being riskier) & 29.8 & 2.04 & 1.665 & .139 & 3.021 & .028 & .794 & .378 & 1.943 & .170 & 2.778 & .102 \\
\hline 3(i)"Market-to-book" ratio (ratio of market value of firm to book value of assets) & 51.0 & 2.31 & .986 & .461 & .385 & .818 & 1.161 & .287 & .423 & .518 & .003 & .958 \\
\hline 3(j)Momentum (recent stock price performance) & 50.0 & 2.19 & .560 & .803 & 1.012 & .412 & .135 & .715 & .751 & .391 & .705 & .405 \\
\hline
\end{tabular}




\begin{tabular}{|c|c|c|c|c|c|c|c|c|c|c|c|c|}
\hline \multicolumn{13}{|c|}{ 4. Choice of discount rates when evaluating a new project in an oversea market } \\
\hline 4(a)The discount rate for our entire company & 59.6 & 2.68 & 2.072 & .063 & 1.103 & .368 & 2.566 & .116 & .655 & .422 & .409 & .526 \\
\hline 4(b)The discount rate for the overseas market (country discount rate) & 74.5 & 3.00 & 1.059 & .412 & 3.472 & .015 & .000 & 1.000 & .000 & 1.000 & 3.077 & 086 \\
\hline 4(c)A divisional discount rate (if the project line of business matches a domestic division) & 72.3 & 3.00 & 1.429 & .216 & 1.910 & 127 & 1.365 & .249 & .915 & .344 & .087 & .770 \\
\hline 4(d)A risk matched discount rate for this particular project (considering both country $\&$ industry) & 78.7 & 3.21 & .951 & 488 & 175 & .950 & .087 & .769 & .006 & 937 & .260 & .612 \\
\hline 4(e)A different discount rate for each component cash flow that has a different risk characteristic (e.g. depreciation Vs. operating cash flow) & 46.8 & 2.34 & 1.238 & .305 & .308 & .871 & .336 & .565 & .164 & .687 & 1.038 & .314 \\
\hline \multicolumn{13}{|c|}{ 5. Preferred mode of foreign investments } \\
\hline 5(a)FDI & 65.2 & 3.04 & 2.047 & .067 & .877 & .486 & 1.185 & .282 & .142 & .708 & .950 & .335 \\
\hline 5(b)Portfolio Investment & 75.0 & 2.86 & 1.247 & .302 & 1.417 & .247 & .133 & .718 & .043 & .836 & .000 & 991 \\
\hline 5(c)Institutional Investment & 59.1 & 2.66 & .997 & .455 & .708 & .592 & .203 & .655 & .403 & .529 & .013 & .911 \\
\hline \multicolumn{13}{|l|}{ 6. Evaluation Criteria } \\
\hline 6(a) Company-wide return criteria for evaluating investment proposals in projects & N.A. & N.A. & .556 & .807 & 1.544 & .206 & .261 & .612 & .252 & .618 & 1.005 & 321 \\
\hline 6(b) different divisional required rates of return for evaluating projects to be undertaken by different divisions or operations & N.A. & N.A. & 1.666 & .142 & .853 & .501 & .742 & .394 & .013 & .911 & .742 & .394 \\
\hline \multicolumn{13}{|c|}{ 7. Use of methods for valuation of Mergers and Acquisitions } \\
\hline 7(a1) Earning Base-discounted cash flow/free cash flow & N.A. & N.A. & .383 & .923 & .673 & 614 & .007 & .932 & .406 & .527 & 086 & .770 \\
\hline 7(a2 ) Earning Based-Cost to create approach & N.A. & N.A. & 1.034 & .430 & 1.347 & .270 & .201 & .656 & 1.294 & .262 & .034 & .856 \\
\hline 7(a3) Earning Based-Capitalized earning method & N.A. & N.A. & .840 & .574 & .556 & .696 & 1.487 & .230 & .442 & .510 & .378 & .542 \\
\hline 7(b1) Market Based-Market Capitalization for listed companies & N.A. & N.A. & 1.687 & .136 & .928 & .458 & .348 & .559 & .061 & .806 & .560 & .459 \\
\hline 7(b2) Market Based-Market multiples for comparable company for unlisted companies & N.A. & N.A. & .400 & .913 & 5.023 & .002 & .244 & .624 & .091 & .764 & 2.048 & .160 \\
\hline 7(b3) Market Based-Tender Prices & N.A. & N.A. & .340 & .944 & $1 . ' 629$ & .186 & .201 & .656 & .157 & .694 & 1.388 & .245 \\
\hline 7(c1) Asset Based--Net adjusted asset value or economic book value & N.A. & N.A. & .369 & .930 & .324 & .860 & 1.182 & .283 & .015 & .904 & .318 & .576 \\
\hline 7(c2) Asset Based Intangible asset valuation & N.A. & N.A. & 2.542 & .027 & 1.088 & .376 & .201 & .656 & 1.294 & .262 & 1.388 & .245 \\
\hline 7(c3) Asset Based- Liquidation Value & N.A. & N.A. & .534 & .822 & .503 & .734 & .151 & .700 & .377 & .542 & .116 & .735 \\
\hline $7(\mathrm{~d})$ Others & N.A. & N.A. & .157 & .994 & .278 & .889 & 1.263 & .272 & .412 & .527 & 1.481 & .235 \\
\hline
\end{tabular}


Appendix 2: Anova Statistics for Financing Decisions

\begin{tabular}{|c|c|c|c|c|c|c|c|c|c|c|c|c|}
\hline \multicolumn{13}{|c|}{ Appendix 2: Anova Statistics for Financing Decisions } \\
\hline & \multirow{2}{*}{$\begin{array}{l}\% \text { of always or } \\
\text { almost of the times }\end{array}$} & \multirow{2}{*}{ Mean } & \multicolumn{2}{|c|}{$\begin{array}{c}\text { Industry } \\
\text { Groups }\end{array}$} & \multicolumn{2}{|c|}{ MNI Rank } & \multicolumn{2}{|c|}{$\begin{array}{l}\% \text { of Foreign } \\
\text { Equity }\end{array}$} & \multicolumn{2}{|c|}{$\begin{array}{l}\text { Consolidated } \\
\text { Assets }\end{array}$} & \multicolumn{2}{|c|}{$\begin{array}{l}\text { Number of foreign } \\
\text { subsidiaries }\end{array}$} \\
\hline & & & $\mathrm{F}$ & Sig. & $\mathrm{F}$ & Sig. & $\mathrm{F}$ & Sig. & $\mathrm{F}$ & Sig. & $\mathrm{F}$ & Sig. \\
\hline \multicolumn{13}{|c|}{ 8. Factors affecting appropriate amount of debt } \\
\hline 8(a) The tax advantage of interest deductibility & 79.2 & 3.19 & 1.959 & .078 & 1.176 & .335 & .020 & .889 & .075 & .785 & 5.542 & .023 \\
\hline 8(b)The potential costs of bankruptcy, near-bankruptcy or financial distress & 55.3 & 2.45 & 1.445 & .210 & 2.683 & .044 & .186 & .668 & .053 & .818 & 3.880 & .050 \\
\hline $8(\mathrm{c})$ The debt levels of other firms in our industry & 72.3 & 2.91 & .952 & .487 & .655 & .627 & .353 & .555 & 1.251 & .269 & 2.946 & .093 \\
\hline 8(d)Our credit rating (as assigned by rating agencies) & 66.7 & 2.90 & .477 & .865 & .611 & .657 & .000 & .995 & .034 & .855 & 3.016 & .089 \\
\hline $8(\mathrm{e})$ The transactions costs \& fees for issuing debt & 61.2 & 2.73 & .194 & .990 & 1.078 & .379 & .090 & .766 & .105 & .748 & .027 & .871 \\
\hline $8(\mathrm{f})$ The personal tax cost our investors face when they receive interest incomes & 54.2 & 2.29 & .832 & .580 & .069 & .991 & 1.115 & .296 & .000 & .984 & .231 & .633 \\
\hline $\begin{array}{l}\text { 8(g)Financial flexibility (we restrict debt so we have enough internal funds available to pursue new projects } \\
\text { when they come along) }\end{array}$ & 59.6 & 2.85 & 1.320 & .263 & .631 & .643 & .411 & .525 & 1.788 & .188 & .213 & .647 \\
\hline $8(\mathrm{~h})$ The volatility of our earnings \& our cash flows & 74.5 & 2.91 & .344 & .943 & .510 & .729 & 1.707 & .198 & .548 & .463 & .916 & .344 \\
\hline 8(i)We limit debt so our customers/suppliers are not worried about our firm going out of business & 57.4 & 2.57 & .945 & .492 & .572 & .684 & 9.167 & .004 & .120 & .730 & .005 & .941 \\
\hline $8(\mathrm{j})$ We try to have enough debt that we are not an attractive takeover target & 34.0 & 2.17 & .627 & .750 & .582 & .677 & .040 & .843 & .150 & .701 & .087 & .770 \\
\hline $8(\mathrm{k})$ If we issue debt our competitors know that we are very unlikely to reduce our input & 42.6 & 2.23 & 1.415 & .222 & .147 & .964 & .500 & .483 & .046 & .832 & .000 & .995 \\
\hline 8(1)A high debt ratio helps us bargain for concessions from our employees & 36.2 & 1.94 & 1.120 & .372 & .679 & .610 & .107 & .745 & 1.454 & .234 & .001 & .981 \\
\hline $\begin{array}{l}8(\mathrm{~m}) \text { To ensure that upper management works hard \& efficiently, we issue sufficient debt to make sure that a } \\
\text { large portion of our cash flow is committed to interest payments }\end{array}$ & 41.3 & 2.13 & 1.353 & .249 & 2.049 & .105 & .026 & .872 & 2.484 & .122 & 1.489 & .229 \\
\hline $\begin{array}{l}\text { 8(n)We restrict our borrowing so that profits from new/future projects can be captured fully by shareholders } \\
\text { \& do not have to be paid as interest to debt holders }\end{array}$ & 38.3 & 2.19 & .701 & .688 & 2.410 & .064 & .931 & .340 & .678 & .415 & .432 & .514 \\
\hline \multicolumn{13}{|c|}{$\begin{array}{ll}\text { 9. Factors affecting firm's decision about issuing foreign debt } \\
\end{array}$} \\
\hline 9(a)Favorable tax payments relative to India (e.g. different corporate tax rates) & 70.5 & 2.80 & .672 & .713 & .417 & .796 & 1.133 & .293 & .346 & .559 & .000 & .987 \\
\hline 9(b) Keeping the "Source of funds" close to the "use of funds". & 68.2 & 3.00 & .351 & .939 & .620 & .651 & .657 & .422 & 1.352 & .251 & .694 & .410 \\
\hline $\begin{array}{l}\text { 9(c) Providing a "natural hedge". (e.g. if the foreign currency devalues, we are not obliged to pay the interest } \\
\text { in Indian Rupee). }\end{array}$ & 81.8 & 3.05 & .794 & .612 & .531 & .714 & .506 & .481 & .148 & .703 & .195 & .661 \\
\hline $9(\mathrm{~d})$ Foreign regulations require us to issue debt abroad & 54.5 & 2.20 & 1.248 & .301 & 1.187 & .332 & 1.019 & .319 & .403 & .529 & 5.887 & .020 \\
\hline 9(e)Foreign interest rates may be lower than domestic interest & 81.8 & 3.23 & 2.018 & .073 & .503 & .734 & 4.837 & .033 & .000 & .988 & .016 & .899 \\
\hline \multicolumn{13}{|c|}{ 10. Factors affecting Indian EMNCs decisions about issuing common equity } \\
\hline 10(a) If our equity price has recently risen, the price at which we can sell is "high" & 72.7 & 2.93 & 2.218 & .050 & .576 & .682 & .004 & .953 & 2.880 & .097 & 1.415 & .241 \\
\hline 10(b)Equity is our "least risky" source of funds & 57.8 & 2.60 & 1.907 & .089 & 1.043 & .397 & .031 & .860 & 5.404 & .025 & .034 & .856 \\
\hline 10(c)Providing shares to employees bonus/stock option plans & 62.2 & 2.78 & 1.258 & .295 & 2.157 & .092 & .518 & .476 & 5.149 & .028 & .034 & .854 \\
\hline 10(d)Common equity is our cheapest source of fund & 65.9 & 2.57 & .896 & .531 & 1.831 & .142 & .207 & .651 & .434 & .514 & 3.200 & .081 \\
\hline 10(e)Maintaining a target debt-to-equity ratio & 66.7 & 2.91 & .745 & .652 & .492 & .741 & 1.584 & 0.215 & 0.458 & 0.502 & 0.178 & 0.675 \\
\hline 10(f)Using a similar amount of equity as is used by other firms in our industry & 55.6 & 2.42 & 1.002 & .451 & .692 & .602 & .692 & .410 & .203 & .654 & 1.933 & .172 \\
\hline $10(\mathrm{~g})$ Whether our recent profits have been sufficient to fund our activities & 60.5 & 2.65 & .732 & .662 & .739 & .571 & .364 & .550 & .055 & .816 & .752 & .391 \\
\hline 10(h)Issuing equity gives investors a better impression of our firm's prospects than issuing debt & 68.2 & 2.77 & 1.552 & .175 & .519 & .722 & .463 & .500 & 3.340 & .075 & .039 & .844 \\
\hline 10(i)The capital gains tax rates faced by our investors (relative to tax rates on dividends) & 52.3 & 2.25 & 1.089 & .394 & 1.524 & .214 & .282 & .598 & .069 & .795 & 3.089 & .086 \\
\hline
\end{tabular}


10(j)Diluting the holding of certain share holders

10(k)The amount by which our equity is undervalued or over valued by the market

10(1)Inability to obtain funds using debt, convertibles, or other sources

$10(\mathrm{~m})$ Earnings-per-share dilution make sure that a large portion of our cash flow is committed to interes

payments

11. Factors affecting Indian EMNCs debt policy

\begin{tabular}{|l|l|c|c|c|c|c|c|c|c|c|c|}
\hline 2.49 & 1.325 & .263 & 1.271 & .298 & .389 & .536 & .620 & .435 & 7.793 & .008 \\
\hline 2.53 & 1.933 & .085 & 1.234 & .312 & .088 & .768 & 2.194 & .146 & 1.505 & .227 \\
\hline 2.29 & .837 & .576 & .680 & .610 & .382 & .540 & .362 & .550 & .855 & .360 \\
\hline 2.58 & .874 & .547 & 1.292 & .289 & 1.116 & .297 & .020 & .890 & .372 & .545 \\
\hline
\end{tabular}

11(a) We issue debt when our recent profits (internal funds) are not sufficient to fund our activitie

11(b)Using debt gives investors a better impressions of our firm's prospects than issuing common stock

11(c)We issue debt when interest rates are particularly low

11(d)We use debt when our equity is undervalued by the market

11(e)We delay issuing debt because of transactions costs \& fees

11(f)We delay retiring debt because of recapitalization costs \& fees

$11(\mathrm{~g})$ Change in the price of our common stock

11(h)We issue debt when we have accumulated substantial profits

\begin{tabular}{|c|}
\hline 66.7 \\
\hline 55.3 \\
\hline 72.3 \\
\hline 57.4 \\
\hline 34.8 \\
\hline 40.4 \\
\hline 51.1 \\
\hline 48.9 \\
\hline
\end{tabular}

\begin{tabular}{|c|c|c|c}
2.77 & 1.042 & .422 \\
\hline 2.60 & .934 & .501 \\
\hline 3.02 & .325 & .951 \\
\hline 2.57 & 2.523 & .026 \\
\hline 2.00 & 1.333 & .258 \\
\hline 2.09 & 2.639 & .021 \\
2.32 & 1.030 & .431 \\
2.30 & .593 & .777
\end{tabular}

12(a) Convertibles are inexpensive way to issue "delayed" common stock

12. Factors affecting Indian EMNC's decision about issuing convertible debt

12(b)Protecting bond holders against unfavorable actions by managers or stock holders

12(c)Convertibles are less expensive than straight debt

12(d)Other firms in our industry successfully use convertibles

12(e)Avoiding short-term equity dilution

12(f)Our stock is currently undervalued

12(g)Ability to "call" or force conversion of convertible debt if/when we need

12(h)To attract investors unsure about the riskiness of our company

72.7

\begin{tabular}{|c|c|c|c|c|c|c|c|}
\hline 1.032 & .402 & .118 & .733 & .175 & .678 & .299 & .587 \\
\hline .952 & .444 & 2.964 & .092 & .264 & .610 & 1.120 & .296 \\
\hline .239 & .915 & .225 & .637 & .976 & .328 & .320 & .574 \\
\hline .667 & .618 & .645 & .426 & .724 & .399 & 1.285 & .263 \\
\hline 2.422 & .064 & 1.708 & .198 & .303 & .585 & .283 & .597 \\
\hline 4.352 & .005 & .610 & .439 & 1.089 & .302 & .115 & .736 \\
\hline .550 & .700 & .226 & .637 & 1.424 & .239 & .156 & .695 \\
\hline .278 & .891 & 1.245 & .270 & .102 & .751 & 2.495 & .121 \\
\hline
\end{tabular}

13. Factors affecting Indian EMNC's choice between Short-term and long -term debt

13(a) We issue short-term when short-term interest rates our low compared to long-term rate

13(b)Matching the maturity of our debt with the life of the debt

13(c)We issue short-term when we are waiting for the long-term market interest rates to decline

13(d)We borrow short-term so that returns from new projects can be captured more fully by shareholders

rather that committing to pay long-term profits as interest to debt holders

13(e)We expect our credit rating to improve, so we borrow short term until it does

13(f)Borrowing short-term reduces the chance that our firm will want to take on risky projects

$13(\mathrm{~g}) \mathrm{We}$ issue long-term rates to minimize the risk of having to refinance in "bad times"

\begin{tabular}{|l|l|}
\hline & 72.7 \\
\hline & 64.3 \\
\hline & 54.4 \\
\hline 55.8 \\
\hline 53.5 \\
\hline 44.2 \\
\hline 54.8 \\
\hline
\end{tabular}

\begin{tabular}{|c|c|c|c|c|}
\hline 2.79 & 1.184 & .338 & .564 & .690 \\
\hline 2.95 & .826 & .586 & 2.955 & .032 \\
\hline 2.44 & 1.953 & .084 & 1.456 & .235 \\
\hline 2.47 & 1.298 & .278 & 1.224 & .317 \\
\hline 2.28 & 1.663 & .144 & 1.332 & .276 \\
\hline 2.50 & 2.627 & .024 & 1.198 & .328 \\
\hline 2.42 & 1.633 & .152 & 3.289 & .021
\end{tabular}

\begin{tabular}{|c|c|}
\hline 68.8 \\
75.0 \\
56.3 \\
43.5 \\
52.2 \\
\hline 40.0 \\
\hline
\end{tabular}

\begin{tabular}{|c|c|c|c|c|c|c|c|c|c|c|}
\hline \\
\hline 2.79 & .985 & .462 & .448 & .773 & .058 & 811 & 6.884 & .012 & .427 & .517 \\
\hline 3.04 & 1.227 & .310 & 1.197 & .326 & 1.421 & .239 & .397 & .532 & .747 & .392 \\
\hline 2.54 & 3.391 & .005 & .836 & .510 & 965 & .331 & 1.335 & . 254 & .295 & .590 \\
\hline 2.28 & 2.306 & .041 & .371 & .828 & .894 & .349 & . 140 & .710 & .045. & .833 \\
\hline 2.50 & .535 & .823 & .747 & .565 & .019 & .891 & .804 & .375 & 2.147 & . 150 \\
\hline 2.24 & .499 & .849 & .753 & . 562 & .010. & .920 & .134 & .716 & 2.358 & 132 \\
\hline 2.84 & .454 & .879 & .434 & .783 & 1.835 & .183 & 3.155 & .083. & .188 & .667 \\
\hline \multicolumn{11}{|c|}{-term finance } \\
\hline N.A. & .425 & .895 & .740 & .572 & .013 & .912 & .123 & .729 & N.A. & N.A. \\
\hline N.A. & 929 & .510 & 1.646 & 190 & 1.197 & 282 & 1.951 & 172 & N.A. & N.A. \\
\hline N.A. & 917 & .525 & 3.529 & .023 & 212 & .649 & .026 & .874 & N.A. & N.A. \\
\hline N.A. & .503 & .798 & 1.036 & .412 & .052 & .822 & .118 & .734 & N.A. & N.A. \\
\hline
\end{tabular}

14(a) Domestic market

14. Preferred markets for raising long-term finance

14(b)International markets other than host country

N.A.

14(c)Host country markets

14(d)Through foreign operations of affiliates

15. Reasons for according higher preference to particular markets to raise funds

15(a) Ease of Acces

15(b)Familiarity with the market/institutions

\begin{tabular}{|l|c|c|c|c|c|c|c|c|c|c|c|c|}
\hline & 89.6 & 3.54 & .839 & .574 & 1.249 & .305 & 3.634 & .063 & .537 & .467 & .120 & .730 \\
\hline & 93.9 & 3.49 & .696 & .693 & .386 & .817 & .017 & .897 & 3.369 & .073 & 1.053 & .310 \\
\hline
\end{tabular}




\begin{tabular}{|c|c|c|c|c|c|c|c|c|c|c|c|c|}
\hline 15(c)Geographical presence & 69.4 & 2.92 & .656 & .726 & .208 & .932 & .022 & .883 & .111 & .741 & .011 & .915 \\
\hline 15(d)Low cost & 93.9 & 3.69 & .693 & .695 & 1.134 & .353 & .348 & .558 & .046 & .831 & .377 & .542 \\
\hline 15(e)Tax benefit & 92.0 & 3.60 & .874 & .546 & .403 & .806 & .403 & .529 & .932 & .339 & .703 & .406 \\
\hline 15(f)Institutional arrangement \& network & 87.8 & 3.47 & .715 & .677 & .545 & .704 & .629 & .432 & .054 & .816 & .144 & .706 \\
\hline $15(\mathrm{~g})$ Others & 53.3 & 2.53 & .993 & .489 & .585 & .681 & .069 & .797 & .820 & .382 & .661 & .431 \\
\hline \multicolumn{13}{|c|}{ 16. Preferred instruments to raise long term finance } \\
\hline 16(a) Equity & 83.3 & 3.38 & .654 & .727 & 2.684 & .044 & .767 & .386 & .046 & .832 & 2.438 & .125 \\
\hline 16(b)Debentures & 74.5 & 3.02 & .743 & .654 & 1.238 & .310 & .530 & .470 & .640 & .428 & 2.634 & .112 \\
\hline 16(c)Foreign Currency Convertible bonds( FCCBs) & 46.8 & 2.43 & 1.053 & .415 & 1.400 & .251 & .115 & .736 & .000 & .991 & 2.282 & .138 \\
\hline 16(d)External Commercial Borrowings ( ECBs) & 45.7 & 2.13 & & 2.466 & .926 & .459 & .103 & .750 & .302 & .585 & .926 & .341 \\
\hline 16(e)Preference Capital & 43.8 & 2.25 & .958 & .482 & .076 & .989 & .373 & .544 & .424 & .518 & .870 & .356 \\
\hline 16(f)GDR & 57.4 & 2.62 & .966 & .476 & .732 & .575 & .926 & .341 & 2.115 & .153 & 1.203 & .279 \\
\hline $16(\mathrm{~g}) \mathrm{ADR}$ & 48.9 & 2.34 & 1.691 & .133 & .533 & .712 & 1.468 & .232 & 1.008 & .321 & 1.259 & .268 \\
\hline 16(h)IDR & 39.0 & 2.20 & .635 & .743 & 1.078 & .382 & 1.041 & .314 & .092 & .763 & 4.145 & .049 \\
\hline 16(i)Term loans from banks \& FI's & 75.0 & 3.06 & 1.256 & .294 & 1.685 & .171 & 1.480 & .230 & .092 & .763 & .860 & .359 \\
\hline 16(j)Interest free loans & 66.0 & 2.89 & 2.029 & .069 & .161 & .957 & 7.818 & .008 & .015 & .903 & .846 & .363 \\
\hline 16(k)Convertible debentures / convertible preference shares & 51.1 & 2.44 & 1.326 & .262 & 1.322 & .278 & .198 & .659 & 1.528 & .223 & .077 & .783 \\
\hline 16(1)others & 30.0 & 1.80 & 7.520 & .037 & .346 & .794 & .139 & .719 & .211 & .659 & .000 & 1.000 \\
\hline \multicolumn{13}{|c|}{ 17. Preferred instruments to raise short term finance } \\
\hline 17(a) Issue of Commercial paper in India & 71.7 & 3.04 & 3.764 & .003 & 1.972 & .117 & .149 & .701 & 5.004 & .030 & .149 & .701 \\
\hline 17(b)Issue of Commercial paper in International markets & 48.9 & 2.33 & 1.661 & .142 & .867 & .492 & 1.583 & .215 & .215 & .646 & .989 & .326 \\
\hline 17(c)Short term- bank loans in India & 74.5 & 3.06 & 2.287 & .042 & 2.454 & .061 & .358 & .553 & .001 & .975 & 2.062 & .158 \\
\hline 17(d)Short term bank loans overseas & 54.3 & 2.48 & 2.005 & .073 & 1.750 & .158 & 4.032 & .050 & .478 & .493 & 2.441 & .125 \\
\hline 17(e)Bills financing through Indian and Foreign banks in India & 53.3 & 2.56 & .882 & .541 & .727 & .579 & 2.771 & .103 & .970 & .330 & 1.687 & .201 \\
\hline 17(f)Bills financing through banks overseas & 42.2 & 2.27 & .891 & .534 & 1.825 & .143 & 3.260 & .078 & .450 & .506 & 1.914 & .174 \\
\hline $17(\mathrm{~g})$ Factoring receivables in India & 44.4 & 2.22 & 1.009 & .447 & 1.336 & .273 & 1.376 & .247 & .089 & .767 & 6.434 & .015 \\
\hline 17(h)Factoring/ receivables overseas & 37.8 & 1.96 & .912 & .518 & .836 & .510 & .170 & .682 & .023 & .879 & 2.701 & .108 \\
\hline 17(i)Forfeiting & 25.0 & 1.64 & .574 & .792 & 1.552 & .206 & .083 & .775 & .005 & .944 & 3.014 & .090 \\
\hline 17(j)Advance payments from customers and associates in India & 53.3 & 2.47 & .380 & .924 & 1.730 & .162 & .277 & .601 & 1.416 & .241 & 7.992 & .007 \\
\hline 17(k)Advance payments from customers and associates overseas & 51.1 & 2.40 & .533 & .824 & 2.050 & .106 & .059 & .809 & 1.357 & .250 & 6.544 & .014 \\
\hline
\end{tabular}




\begin{tabular}{|c|c|c|c|c|c|c|c|c|c|c|c|c|}
\hline \multicolumn{13}{|c|}{ Appendix 3: Anova Statistics for Dividend Decisions } \\
\hline & \multirow{2}{*}{$\%$ of always or almost of the times } & \multirow{2}{*}{ Mean } & \multicolumn{2}{|c|}{ Industry Groups } & \multicolumn{2}{|c|}{ MNI Rank } & \multicolumn{2}{|c|}{$\%$ of Foreign Equity } & \multicolumn{2}{|c|}{ Consolidated Assets } & \multicolumn{2}{|c|}{ Number of foreign subsidiarie } \\
\hline & & & $\mathrm{F}$ & Sig. & $\mathrm{F}$ & Sig. & $\mathrm{F}$ & Sig. & $\mathrm{F}$ & Sig. & $\mathrm{F}$ & Sig. \\
\hline \multicolumn{13}{|c|}{ 18. To what extent co. remit foreign earnings } \\
\hline 18. To what extent co. remit foreign earnings & N.A. & N.A. & 2.241 & .049 & .776 & .548 & 1.128 & .294 & 1.648 & .206 & .808 & .374 \\
\hline \multicolumn{13}{|c|}{ 19. Type of Dividend } \\
\hline 19(a) Cash Dividend & 65.3 & 2.69 & 1.657 & .139 & .797 & .533 & .896 & .349 & .328 & .570 & .241 & .626 \\
\hline 19(b) Stock Dividend & 64.6 & 2.75 & .937 & .498 & 2.074 & .101 & 1.945 & .170 & .193 & .662 & .244 & .624 \\
\hline \multicolumn{13}{|c|}{ 20. Characterization of co.'s dividend policy } \\
\hline 20. Characterization of co.'s dividend policy & N.A. & N.A. & 1.861 & .097 & 2.810 & .038 & .394 & .533 & 1.183 & .283 & N.A. & N.A. \\
\hline
\end{tabular}

\begin{tabular}{|c|c|c|c|c|c|c|c|c|c|c|c|c|}
\hline \multicolumn{13}{|c|}{ Appendix 4: Anova Statistics for Management Control Decisions } \\
\hline & \multirow{2}{*}{$\%$ of always or almost of the times } & \multirow{2}{*}{ Mean } & \multicolumn{2}{|c|}{ Industry Groups } & \multicolumn{2}{|c|}{ MNI Rank } & \multicolumn{2}{|c|}{$\%$ of Foreign Equity } & \multicolumn{2}{|c|}{ Consolidated Assets } & \multicolumn{2}{|c|}{ Number of foreign subsidiarie } \\
\hline & & & F & Sig. & $\mathrm{F}$ & Sig. & $\mathrm{F}$ & Sig. & $\mathrm{F}$ & Sig. & F & Sig. \\
\hline \multicolumn{13}{|c|}{ 21. Criteria for financial performance measurement of foreign operations of Indian EMNCs } \\
\hline 21(a) One company wide ROI criteria & 80.0 & 3.07 & 1.243 & .303 & 1.206 & .323 & .243 & .625 & 1.462 & .233 & 2.322 & .135 \\
\hline 21(b)Separate ROI for each country operation & 65.2 & 2.72 & 1.185 & .334 & .462 & .763 & 1.152 & .289 & 4.156 & .048 & .015 & .902 \\
\hline 21(c)EVA /Residual income & 51.1 & 2.40 & 1.443 & .213 & .934 & .454 & .368 & .547 & .492 & .487 & .028 & .867 \\
\hline 21(d)Net Cash flow & 80.4 & 3.09 & 1.586 & .162 & 1.192 & .329 & .504 & .482 & .063 & .802 & 4.666 & .036 \\
\hline 21(e)Free cash flow & 71.7 & 2.96 & 2.871 & .014 & 2.481 & .059 & .075 & .785 & .245 & .623 & 2.751 & .104 \\
\hline 21(f)Return on Equity & 80.4 & 3.17 & 1.350 & .251 & .401 & .807 & .011 & .919 & .322 & .573 & .964 & .332 \\
\hline \multicolumn{13}{|c|}{ 22. Transfer Pricing Techniques } \\
\hline 22(a) Cost plus pricing & 34.8 & 2.94 & .818 & .592 & .782 & .544 & 1.243 & .271 & .041 & .840 & 5.310 & .026 \\
\hline 22(b)Contribution approach & 45.7 & 1.87 & .889 & .536 & .131 & .970 & .006 & .937 & .081 & .778 & .557 & .459 \\
\hline 22(c)Negotiated prices & 44.4 & 2.00 & .896 & .530 & .791 & .538 & .000 & 1.000 & .502 & .483 & .455 & .503 \\
\hline 22(d)At arm's length & 34.0 & 2.16 & 1.100 & .386 & .710 & .590 & .040 & .843 & .002 & .969 & 5.795 & .020 \\
\hline
\end{tabular}

